\title{
Distribution and damage of powdery mildew disease in cassis and raspberry in Tashkent province, Uzbekistan
}

\author{
Gayrat Jumanazarov $^{1 *}$, Mirakbar Zuparov ${ }^{1}$, Mukhiddin Mamiev ${ }^{1}$, and Abdurakhmon \\ Allayarov ${ }^{1}$ \\ ${ }^{1}$ Tashkent State Agrarian University, 100140 Tashkent province, Uzbekistan
}

\begin{abstract}
This article provides information on the species composition of the powdery mildew pathogen found in medicinal plants cassis and raspberry, as well as its distribution, development and damage to farms in the Tashkent province. The development of raspberry powdery mildew in the farms studied and the relatively low yield loss may depend on the raspberry navigation planted on the farm, the agronomic practices carried out, and the disease control measures taken. The prevalence of powdery mildew in cassis was $25.6-49.8 \%$, development was $14.2-27.1 \%$, yield loss was $12.0-20.0 \%$, and the prevalence of powdery mildew in raspberry was $12.5-31.4 \%$, development was $5.3-25.2 \%$, and yield loss was $10.9-22.7 \%$.
\end{abstract}

\section{Introduction}

According to the FAO, more than 662,500 tons of raspberries and cassis, which are medicinal plants, were harvested in 2018. Russia is the world's largest producer of these medicinal plants, with 59,674,000 tons harvested in 2018, followed by Poland $(42,642,000$ tons), Ukraine (4,700,000 tons), the United Kingdom (2,552,000 tons) and Germany $(2,247,000$ tons) grown in other countries [1,2].

The plant world is one of the riches of nature. It is known that the properties of medicinal plants have been known since ancient times and they have been used to treat various diseases [3, 4].

The fragrant taste of cassis and raspberry is loved and consumed due to the high content of vitamin $\mathrm{C}$ and mineral salts necessary for the body, as well as its healing properties. Raspberry fruit contains vitamins C, B, and cassis fruit contains vitamins B12, A, P, K, sugar, organic acids, fragrant substances in addition to the above vitamins $[5,6]$.

$45 \%$ of preparations used in scientific medicine are extracted from plants or prepared from them [7]. Of the 230 species of medicinal plants grown in the country, 159 species are cultivated plants [8]. It can be said that in 2019, products from processed medicinal plants worth \$ 48 million were exported [9]. Among them cassis and raspberry medicinal plants have a special place. Diseases found in these plants have been observed to reduce not only their yield but also their quality.

* Corresponding author: g.jumanazarov@,yandex.ru 
A number of studies have been conducted in countries where this medicinal plant is grown to study raspberry diseases. Its most common diseases are anthracnose, red spots, rust, white spots, gray rot, bacterial cancers of stems and roots, wound-forming spots, powdery mildew, vertitsellez and fusarium wilt, root rot, leaf spot, phyllosticosis, bacteriosis and viral infections [10].

Cassis's powdery mildew, or spheroteka disease, is native to North America, from where the disease entered Europe and later spread to other countries. The causative agent of this disease has long been considered only a gooseberry-adapted obligate parasite [11]. But later it was noted that this type of fungus, which causes powdery mildew, also causes severe damage to the cassis [12].

Red cassis branches take longer to develop than black cassis. Therefore, severe infestation with black cassis powdery mildew disease has been observed [13]. The golden cassis, which is grown as an ornamental shrub, is strongly susceptible to powdery mildew [14]. In addition, strong damage to the mother bushes of white cassis and black cassis with powdery mildew disease has been reported [15].

Black cassis is more prone to powdery mildew than others [15]. The pathogenic fungus is adapted to the tissue of the young twigs of the host plant [16], infecting its young twigs growth point, leaf blade and plate, fewer buds and fruits, often fruit twigs and fruit bands [17]. The difference between powdery mildew-causing fungi and other fungi that cause disease in plants is that they produce mycelium in two different forms. The mycelium in the first appearance is thin, clings to the surface of the damaged substrate with the help of appressors, and forms gaustoria, with the help of which it obtains the necessary nutrients and water for itself from the plant cell. The mycelium of the second appearance, which is formed later, is brown, the walls are thick, and they adapt to adverse conditions and help to survive until the next year [18].

More damage from powdery mildew disease is observed when the growth point of the bushes is damaged. In this case, the space between the joints of the stem and branches becomes shorter. The leaves formed in them are small, colorless, often deformed [1-3]. The development of diseased fruits is slow, if the disease is severe; they twist and fall off [7]. When black cassis is infested with powdery mildew as well as bud buds, it causes irregular growth and deformation of the branches formed by cutting the branches against insects or shrubs for rejuvenation [19].

When Cassis suffers from powdery mildew, its leaves are covered on both sides with white dust consisting of mycelium and conidia of the fungus. Later, the branches of the plant are completely covered with such dust [8].

Fungi that cause powdery mildew in plants are adapted to relatively dry weather [5] and are light-loving fungi [6]. Their mycelium thickens in autumn and turns brown. Then, among the mycelium, the fruit bodies of the fungus in the form of dark-colored dots form cleistothecia [5]. With the help of these fruits, the fungus can overwinter in plant debris, twigs and stems, or mycelium can be stored in plant buds.

The spores of the fungus in the sac mature in the spring and damage the growth point of cassis twigs as well as young leaves. The flight of spores from the sacs takes 1-1.5 months, and for their germination the humidity should be sufficient and the air temperature should not be less than $15-17^{\circ} \mathrm{C}[10]$. Occurrence of Powdery mildew in cassis was observed in the last ten days of May in Almaty conditions [11]. In the study of powdery mildew disease of cassis in the North-Western region of Russia, the early onset of this disease was observed (Pavlova, 1955). It is now noted that the disease occurs during the entire growing season of cassis, mainly in the second half of summer [11].

Powdery mildew disease has been found to be $73-77 \%$ more prevalent in newly planted areas of black cassis than in the old [1-3]. Stem growth decreased 1.6-2.2-fold [3]. 


\section{Materials and methods}

In experiments, the species composition of diseases common in cassis and raspberry plants was studied.

Experiments to study the species composition of cassis and raspberry plants in 20172019 in the fields of "M. Mirzaev Fruit, Viticulture and Enology Research Institute" (next, RI named after M. Mirzaev), "Kumushkon Botirali", "Kumushkon Gold" and "BB Agro 1" farms in Tashkent province, Uzbekistan, as well as cassis and raspberry determination of the species composition of the causative agent of powdery mildew of plants and laboratory experiments were carried out at the Department of Agrobiotechnology of Tashkent State Agrarian University.

Microscopes MIKMED-5, Optics B-292PLI, NiB-100 were used to identify pathogenic fungal species [19]. Identifiers of NM Pidoplichko, VI Bilay and others [1-4, 19] were used to identify fungal species. The prevalence and development of diseases in cassis and raspberry plants were determined using the methods of Chumakov [19].

As a method of determining the development of diseases of raspberry and cassis plants, the expression of the percentage of infected plants in a given area is called the prevalence of the disease and it was found based on the following equation (1) [19]:

$$
\mathrm{P}=\mathrm{n} / \mathrm{N} \times 100
$$

where, $\mathrm{P}$ - disease prevalence, $\% ; \mathrm{N}$ - total number of plants counted; and, $\mathrm{n}$ - number of diseased plants in the sample.

The prevalence of the disease on the farm was determined using the following equation (2):

$$
\mathrm{Pu}=\Sigma(\mathrm{S} \times \mathrm{P}) / \mathrm{S}
$$

where, $\mathrm{P}_{\mathrm{u}}$ - farm prevalence of the disease, $\% ; \Sigma(\mathrm{S} \times \mathrm{P})$ - sum of the area of the observed field multiplied by the percentage of disease prevalence in each field; and, $\mathrm{S}$ - total area of the observed field.

The degree of damage to diseased plants was determined on a 5-point scale or percentage. The development of diseases of medicinal plants was found using the following equation (3):

$$
\mathrm{R}=\Sigma(\mathrm{a} \times \mathrm{b}) / \mathrm{N}
$$

where, $\mathrm{R}$ - average rate of disease, $\% ; \Sigma(\mathrm{a} \times \mathrm{b})$ - sum of the number of plants (a) multiplied by the corresponding points or percentages of the disease (b); and, $\mathrm{N}$ - number of diseased plants.

Fruit weight was taken into account to determine the decrease in yield. The number of plants in the tested samples was taken from 10. The number of healthy and diseased medicinal plants in the samples was calculated and, expressing the difference between the number of sick and healthy plants as a percentage, the disease damage was found by the following equation (4):

$$
\mathrm{B}=(\mathrm{A}-\mathrm{a}) / \mathrm{A} \times 100
$$

where, B - lost yield, \%; A - total plant yield; and, a - yield of the diseased plant. 


\section{Results and discussion}

Fungi that cause powdery mildew in plants make up one-tenth of the fungal species recorded in Uzbekistan [2]. Most of these fungi are adapted to dry climates, but there are also many moisture-loving species among them. Such a difference can also be observed between species belonging to the same genus.

In Tashkent province, the causative agent of powdery mildew in the cassis is Leveillula saxifragacearum Golov. $f$. ribis Golov fungus species Ascomycota filumi, class Euascomycetes, order Erysiphales, family Erysiphaceae (anamorphic Deuteromycetia, Photype Hyphiasia, group Anphorica Deuteromycetes). With powdery mildew disease caused by Leveillula saxifragacearum, it was noted that the leaves, twigs, petals of cassis were damaged. The affected organs of the cassis were covered with sparse and then dense white dust, consisting first of mycelium, conidia, and conidia of the fungus. Diseased branches lag behind in growth and development. The damaged leaves were crushed and turned yellowish-brown. Due to the disease shed flowers, whose petals were damaged, and the fruit of the tree of the knowledge of good and evil was withered and withered. It was observed that the white dust produced by the pathogenic fungus persists for a long time in the affected plant organs.

The primary conidia of the fungus that cause cassis powdery mildew are lanceolate in shape, measuring 38-80 × 11-19 $\mu \mathrm{m}$, and averaging 56.1-13.7 $\mu \mathrm{m}$. Secondary conidia are also cylindrical or slightly enlarged in the third part, measuring $42-63 \times 12-18 \mu \mathrm{m}$. Conidia are long, cleistothecia dark brown, large, $150 \times 255 \mu \mathrm{m}$ in diameter. The structure of the peridia is uncertain. When crushed, it was found that the cells in it were angular and had a diameter of 9-12 $\mu \mathrm{m}$. It was noted that the tumors of Cleistothecia were once branched, angular-serpentine, and they did not last long, and their size was found to be $60-90 \times 6 \mu \mathrm{m}$. It was noted that the Clytothecia had many sacs, which were elliptical in shape and measuring 60-75 $\times 27-32 \mu \mathrm{m}$. Ascospores were found to be elliptical and measuring 27-33 $\times 12-15 \mu \mathrm{m}$ (Fig. 1).
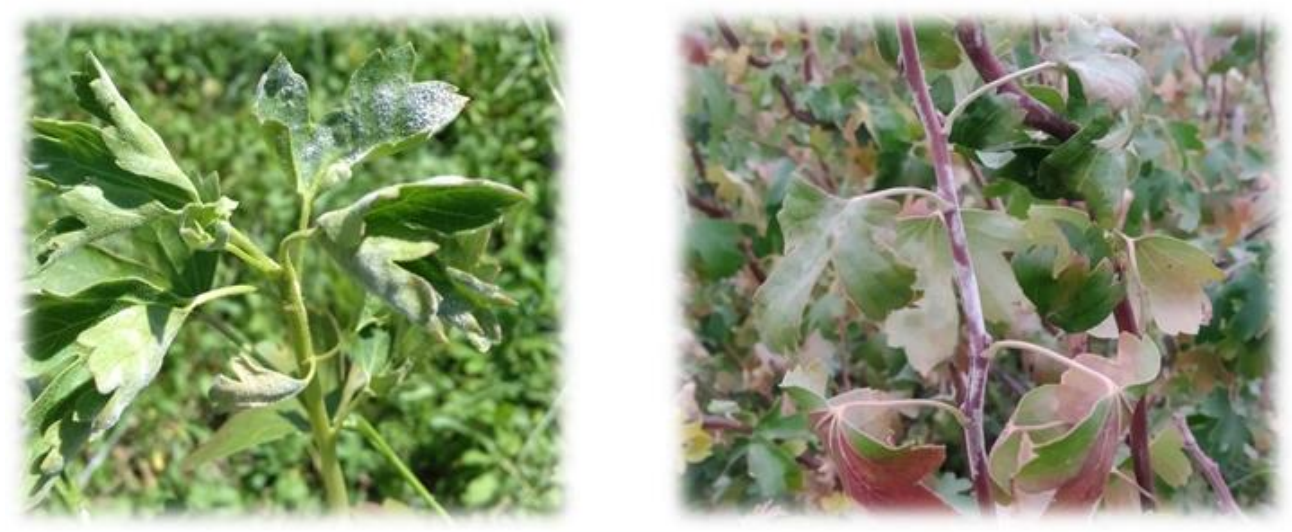

Fig. 1. Infection of leaves and twigs of Cassis with powdery mildew disease.

When analyzing the incidence of Cassis powdery mildew in farms of Tashkent province in 2017-2019, its prevalence and development was higher in 2018, with 33.1-49.8 and 18.4$27.1 \%$, respectively (see Table 1 ). This figure was $26.4-42.3 \%$ and $15.2-24.1 \%$ in 2017 , respectively, and in 2019 it was $25.6-41.2 \%$ and $14.2-23.1 \%$.

Such a difference in the occurrence of powdery mildew disease over the years can be attributed to the fact that the dry weather and slightly higher temperatures in 2018 
compared to other years are favorable for the development of this pathogenic fungal species.

The incidence of powdery mildew in farms was higher in the RI and "BB Agro 1" farm, its prevalence in these farms was $41.2-49.8 \%$ and $33.1-41.8 \%$, while $23.1-27.1 \%$ and $19.5-$ $20.3 \%$, respectively. This figure is $27.4-28.6 \%$ and $25.6-26.4 \%$ and $15.3-16.5 \%$ and $14.2-$ 15 , respectively, in "Kumushkon Gold" and "Kumishkon Botirali" farms. It was noted that it was $2 \%$.

Table 1. Prevalence and development of powdery mildew disease in cassis plant.

\begin{tabular}{|c|c|c|c|c|c|c|c|c|c|c|}
\hline \multirow[b]{3}{*}{ \# } & \multirow[b]{3}{*}{ Smallholders } & \multicolumn{3}{|c|}{2017} & \multicolumn{3}{|c|}{2018} & \multicolumn{3}{|c|}{2019} \\
\hline & & \multicolumn{9}{|c|}{ Disease } \\
\hline & & 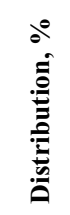 & $\begin{array}{l}\stackrel{0}{0} \\
\stackrel{0}{0} \\
\frac{0}{0} \\
\frac{0}{0} \\
\stackrel{0}{0}\end{array}$ & 递 & 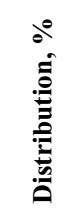 & 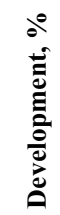 & 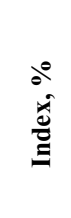 & 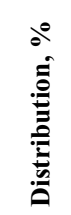 & $\begin{array}{l}\stackrel{0}{0} \\
\stackrel{\Xi}{0} \\
\frac{0}{0} \\
\frac{0}{0} \\
\stackrel{0}{0}\end{array}$ & $\frac{\partial}{0}$ \\
\hline 1 & $\begin{array}{c}\text { Research Institute } \\
\text { named after M. } \\
\text { Mirzaev }\end{array}$ & 42.2 & 24.1 & 10.2 & 49.8 & 27.1 & 13.5 & 41.2 & 23.1 & 9.5 \\
\hline 2 & $\begin{array}{l}\text { "Kumushkon Botirali" } \\
\text { farm }\end{array}$ & 26.4 & 15.2 & 4.0 & 33.1 & 18.4 & 6.1 & 25.6 & 14.2 & 3.6 \\
\hline 3 & $\begin{array}{l}\text { "Kumushkon Gold" } \\
\text { farm }\end{array}$ & 28.6 & 16.5 & 4.3 & 35.2 & 19.5 & 6.9 & 27.4 & 15.3 & 4.2 \\
\hline \multirow[t]{2}{*}{4} & "BB Agro 1" farm & 34.7 & 20.3 & 7.0 & 41.8 & 23.2 & 9.7 & 33.1 & 19.5 & 6.4 \\
\hline & $\mathrm{LSD}_{05}$ & \multicolumn{3}{|c|}{1.57} & \multicolumn{5}{|c|}{1.02} & 0.52 \\
\hline
\end{tabular}

The effect of Powdery mildew disease on the yield of cassis was also studied. In the farms surveyed, the loss of currant due to the disease was $12.0-20.0 \%$. At the same time, $20.0 \%$ in the RI, $18.0 \%$ in "BB Agro 1", $15.7 \%$ in "Kumushkon Gold", and $12.0 \%$ in "Kumushkon Botirali” farms yield loss was noted (see Table 2).

Table 2. Effect of Powdery mildew disease on cassis yield (2017-2019).

\begin{tabular}{|c|c|c|c|c|c|c|c|c|c|}
\hline \multirow{2}{*}{ \# } & \multirow{2}{*}{ Smallholders } & \multirow{2}{*}{ 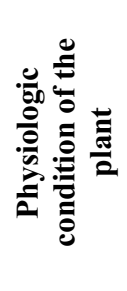 } & \multirow{2}{*}{ 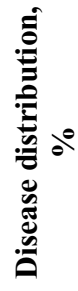 } & \multicolumn{3}{|c|}{$\begin{array}{c}\text { Disease } \\
\text { development, \% }\end{array}$} & \multirow{2}{*}{ 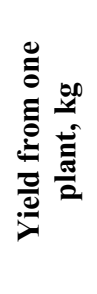 } & \multicolumn{2}{|c|}{$\begin{array}{c}\text { Yield loss } \\
\text { relative to } \\
\text { healthy plants }\end{array}$} \\
\hline & & & & త్త & 氖 & 竞 & & kg & $\%$ \\
\hline \multirow{2}{*}{1} & \multirow{2}{*}{$\begin{array}{c}\text { Research } \\
\text { Institute named } \\
\text { after M. Mirzaev }\end{array}$} & healthy & - & - & - & - & 3.00 & - & - \\
\hline & & affected & 44.5 & 24.2 & 11.4 & 2.7 & 2.40 & 0.60 & 20.0 \\
\hline \multirow{2}{*}{2} & \multirow{2}{*}{$\begin{array}{l}\text { "Kumushkon } \\
\text { Botirali" farm }\end{array}$} & healthy & - & - & - & - & 2.50 & - & - \\
\hline & & affected & 28.4 & 15.9 & 6.2 & 1.1 & 2.20 & 0.30 & 12.0 \\
\hline \multirow{2}{*}{3} & \multirow{2}{*}{$\begin{array}{l}\text { "Kumushkon } \\
\text { Gold" farm }\end{array}$} & healthy & - & - & - & - & 3.50 & - & - \\
\hline & & affected & 30.4 & 17.1 & 7.3 & 2.1 & 2.95 & 0.55 & 15.7 \\
\hline \multirow{2}{*}{4} & \multirow{2}{*}{$\begin{array}{l}\text { "BB Agro 1" } \\
\text { farm }\end{array}$} & healthy & - & - & - & - & 2.50 & - & - \\
\hline & & affected & 36.5 & 21.0 & 8.8 & 2.2 & 2.05 & 0.45 & 18.0 \\
\hline
\end{tabular}


Powdery mildew disease may be more prevalent and relatively higher than other farms in the RI due to agrotechnical measures taken against the planted cassis navigation and measures taken against the disease.

As a result of observations in the fields of raspberry farms in Tashkent province, powdery mildew was detected in all plantations.

The telemorph of the pathogenic species Sphaerotheca macularis Magnus is Ascomycota phylum, class Euascomycetes, order Erysiphales, family Erysiphaceae (anamorphic Deuteromycetes group of fungi, order Hyphomycetia oles, Hyphomycetes class).

Growing twigs of raspberry, young leaves were damaged by powdery mildew. The reticular white dust of the pathogenic fungus appeared on the upper and lower surface of the young leaves, in a certain part of the leaf blade, and rarely on the third part of the growing branches. When the humidity was high enough, the dust took on a powdery appearance and became noticeable. Under unfavorable conditions for the growth of the fungus, the dust was not visible, as the hairs covering the leaves of the raspberry prevented this. Diseased leaves stopped growing, discolored, the petals became thinner. Dust in plant organs was found to consist of fungal mycelium and conidia.

During the formation of the conidia (Oidium $s p$ ) its conidia coalesced to form a chain, which had an elongated barrel-like appearance, covered with a colorless, thin film, measuring $27-36 \times 15-17 \mu \mathrm{m}$.

Studies have not shown that the fungus that causes this disease produces cleistothecia belonging to the sac-forming period.

As a result of research on raspberry fields in "Kumushkon Bakht", "Kumushkon Gold" and "BB Agro 1" farms in Tashkent province, it was noted that the disease is less common in "BB Agro 1" farms. It was observed that the prevalence of powdery mildew disease in this farm was $12.5 \%$ and the development was 5.3\% (see Table 3). This indicator was $28.2 \%$ and $22.7 \%$ in "Kumushkon Bakht" and $31.4 \%$ and $25.2 \%$ in "Kumushkon Gold" farms, respectively.

Table 3. Prevalence, development and effect of powdery mildew on raspberry (2017-2019)

\begin{tabular}{|c|c|c|c|c|c|c|c|c|}
\hline \multirow{3}{*}{ \# } & \multirow{3}{*}{ Smallholders } & \multicolumn{3}{|c|}{ Disease } & \multirow{2}{*}{\multicolumn{2}{|c|}{$\begin{array}{l}\text { Yield from one plant, } \\
\mathrm{kg}\end{array}$}} & \multirow{2}{*}{\multicolumn{2}{|c|}{$\begin{array}{c}\text { Yield loss } \\
\text { relative to } \\
\text { healthy plants }\end{array}$}} \\
\hline & & \multirow{2}{*}{ 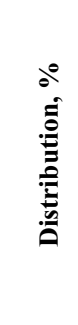 } & \multirow{2}{*}{ 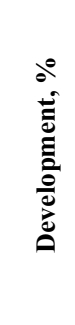 } & \multirow{2}{*}{ 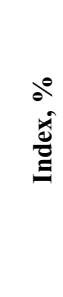 } & & & & \\
\hline & & & & & Healthy & Affected & kg & $\%$ \\
\hline 1 & $\begin{array}{l}\text { "Kumushkon Bakht" } \\
\text { farm }\end{array}$ & 28.2 & 22.7 & 6.4 & 2.50 & 2.00 & 0.50 & 20.0 \\
\hline 2 & $\begin{array}{l}\text { "Kumushkon Gold" } \\
\text { farm }\end{array}$ & 31.4 & 25.2 & 7.9 & 2.20 & 1.70 & 0.50 & 22.7 \\
\hline 3 & "BB Agro 1" farm & 12.5 & 5.3 & 5.9 & 2.30 & 2.10 & 0.25 & 10.9 \\
\hline & $\mathrm{LSD}_{05}$ & 1.17 & & & & & & \\
\hline
\end{tabular}

When analyzing the effect of powdery mildew disease on the yield of raspberry plant, it was observed that due to this disease, relatively fewer yields were lost on the farm "BB Agro 1" and the figure was $10.9 \%$. Loss of crops due to the disease was $20.0 \%$ at "Kumushkon Bakht" farm and 22.7\% at "Kumushkon Gold" farm (Fig. 2). 


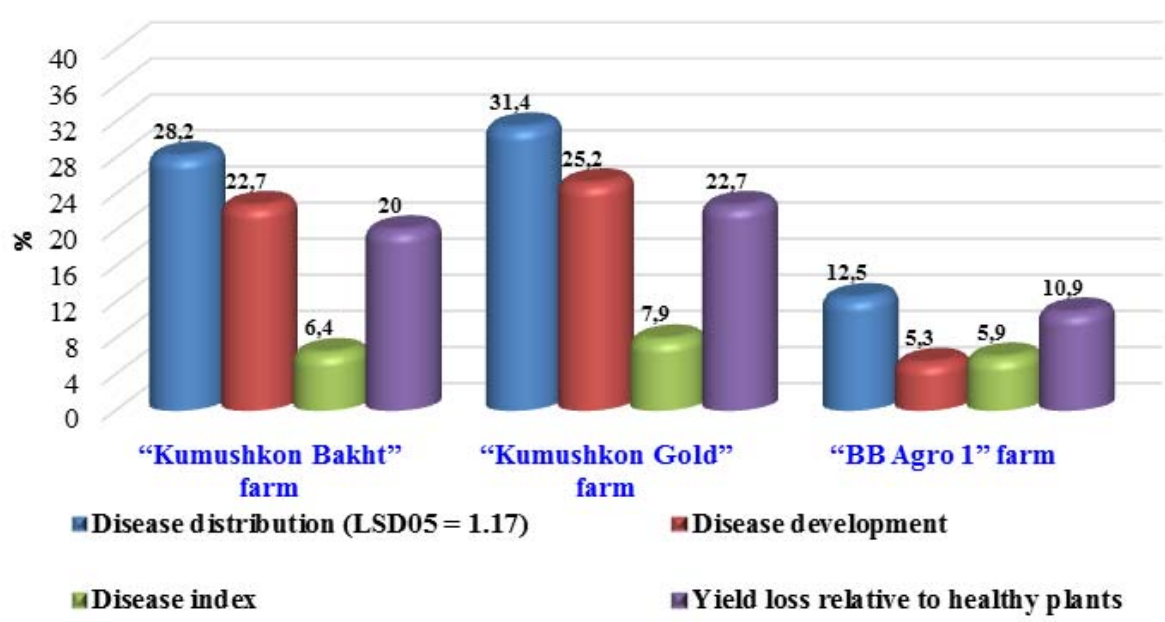

Fig. 2. Prevalence, development and effect of powdery mildew disease on raspberry (2017-2019).

The prevalence and development of raspberry powdery mildew in the farms studied and the relatively low yield loss on the "BB Agro 1" farm may depend on the raspberry navigation planted on the farm, the agronomic practices carried out, and the disease control measures taken.

\section{Conclusions}

In Tashkent province, powdery mildew caused by the fungus Leveillula saxifragacearum Golov. f. ribis Golov. in the cassis and Sphaerotheca macularis Magnus in the raspberry was detected in all farms surveyed.

The prevalence of powdery mildew in cassis was 25.6-49.8\%, development was 14.2$27.1 \%$, yield loss was $12.0-20.0 \%$, and the prevalence of powdery mildew in raspberry was 12.5-31. , 4\%, development was 5.3-25.2\%, and yield loss was $10.9-22.7 \%$.

\section{References}

1. R. Abdullaev, Fruits grown in the garden, 30 (1991)

2. N.Ch. Namozov, D.A. Kodirova, M.I. Usmonova, International journal of scientific \& technology research, 9(03), 5491-5493 (2020)

3. M. Urmanova, A. Kuziev, D. Burkhanova, D. Kadirova, N. Namozov, N. Shadieva, E3S Web of Conferences, 244, 02036 (2021)

4. V.I. Bilay, Fusarium, 443 (1977)

5. A.D. Burmistrov, Agropromizdat, 108 (1985)

6. E.A. Vlasova, Plant Protection, 9, 63-66 (1971)

7. S. Islamov, N. Namozov, M. Saidova, D. Kodirova, E3S Web of Conferences, 244, 03028 (2021)

8. N. Namozov, M. Tursinbaev, I. Yuldoshev, S. Yuldasheva, E3S Web of Conferences, 244, 02007 (2021)

9. P.N. Golovin, Microflora of Central Asia, 1, 145 (1949)

10. T.S. Zvyagina, Breeding and variety study in intensive gardening, 29-33 (1980) 
11. M. Karimov, N. Namozov, B. Teshaboev, E3S Web of Conferences, 244, 02025 (2021)

12. R.A. Kulmatov, A.A. Kist, IND. LAB, 44(12), 1689-1692 (1978)

13. B. Abdullaev, R.A. Kulmatov, A.A. Kist, Industrial Laboratory (USSR) (English translation of Zavodskaya Laboratoriya), 54(7), 710-713 (1989)

14. V.M. Emets, R.A. Kulmatov, Doklady Biological Sciences, 271(1-6), 370-372 (1983)

15. V.S. Savenko, R.A. Kulmatov, Geochemistry International, 35(11), 1028-1030 (1997)

16. Y. Gafforov, R. Phookamsak, H.-B. Jiang, D. N. Wanasinghe, M. Juliev, Botany, 97(12), 671-680 (2019)

17. A. Djuraev, D. Mirdjalalov, A. Nuratdinov, T. Khushvaktov, Y. Karimov, E3S Web of Conferences, 258, 03017 (2021)

18. R.A. Kulmatov, V.S. Savenko, N. Dalonov, Geochemistry International, 29(5), 140148 (1992)

19. G.Kh. Jumanazarov, M.A. Zuparov, International Journal of Agriculture, Environment and Bioresearch, 5(5), 191-198 (2020) 